\title{
ESTIMASI JARAK GENETIK DAN FAKTOR PEUBAH PEMBEDA BANGSA BABI (Berkshire, Duroc, Landrace dan Yorkshire) MELALUI ANALISIS MORFOMETRIK DI BPTU BABI DAN KERBAU SIBORONGBORONG
}

\author{
(Genetic Distance Estimation and Variable Differential Factor of Pig Breeds \\ (Berkshire, Duroc, Landrace and Yorkshire) Through Morphometrics Analysis \\ in BPTU Pig and Buffalo Siborongborong)
}

\author{
Netro Banjarnahor ${ }^{1}$, Usman Budi ${ }^{2}$ dan Hamdan ${ }^{2}$
}

1. Mahasiswa Program Studi Peternakan Fakultas Pertanian Universitas Sumatera Utara

2. Staff Pengajar Program Studi Peternakan Fakultas Pertanian Universitas Sumatera Utara

\begin{abstract}
Genetic distances provide little opportunity to obtain heterosis in crosses. Therefore the genetic distance be a guide in conducting cross. The object of the research to identify factors differentiating variables and estimate the genetic distance between the pig breeds (Berkshire, Duroc, Landrace and Yorkshire). This research was conducted in the Superior Livestock Breeding Center, (BPTU) Pig and Buffalo Siborongborong using Berkshire (17 pigs), Duroc (22 pigs), Landrace (46 pigs) and Yorkshire (25 pigs). Data collection was done by measuring the observed variables are shoulder height, hip height, hip width, body length, chest girth, inchest, tail length, neck circumference, head length, head width, ear length and ear width. The data obtained were processed using a simple discriminant analysis using the SAS program (Statistical Analysis System) and Dendogram using the program MEGA (Molecular Evolutionary Genetic Analysis). The results showed that the phenotypically purity of Berkshire pigs (88.24\%), Duroc pigs (86.36\%), Landrace pigs (89.13\%) and Yorkshire pigs (68.00\%). Variable differential factor for body morphometrics was ear width, ear length, head width, head length and tail length. Berkshire and Yorkshire has a close genetic distance, while the Duroc and Landrace has a far genetic distance.
\end{abstract}

Keywords : Pig, Morphometrics, Genetic distance, Phenotypically purity.

\begin{abstract}
ABSTRAK
Jarak genetik yang dekat memberikan peluang yang sedikit untuk mendapatkan heterosis dalam persilangan. Oleh karena itu jarak genetik menjadi pedoman dalam melakukan persilangan. Penelitian ini dilakukan untuk mengetahui faktor peubah pembeda dan mengestimasi jarak genetik diantara bangsa babi (Berkshire, Duroc, Landrace dan Yorkshire). Penelitian ini dilakukan di Balai Pembibitan Ternak Unggul, Siborongborong menggunakan 17 ekor babi Berkshire, 22 ekor Duroc, 46 ekor Landrace dan babi Yorkshire 25 ekor. Pengambilan data dilakukan dengan cara mengukur tinggi pundak, tinggi pinggul, lebar pinggul, panjang badan, lingkar dada, dalam dada, panjang ekor, lingkar leher, panjang kepala, lebar kepala, panjang telinga dan lebar telinga. Data yang diperoleh diolah dengan analisis diskriminan sederhana dengan menggunakan program SAS (Statistical Analysis System) dan Dendogram menggunakan program MEGA (Molekuler Evolusioner Genetic Analysis). Hasil penelitian menunjukkan bahwa kemurnian fenotifik masing-masing bangsa babi ialah bangsa Berkshire $(88,24 \%)$, bangsa Duroc (86,36\%), bangsa Landrace $(89,13 \%)$ dan Yorkshire $(68,00 \%)$. Faktor peubah pembeda morfologi tubuh dari keempat bangsa babi ialah lebar telinga, panjang telinga, lebar kepala, panjang kepala dan panjang ekor. Jarak genetik babi Berkshire dengan babi Yorkshire memiliki jarak genetik yang dekat, sebaliknya babi Duroc dengan babi Landrace memiliki jarak genetik yang jauh.
\end{abstract}

Kata kunci: Babi, Morfometrik, Jarak genetik, Kemurnian fenotifik. 


\section{PENDAHULUAN}

Babi adalah ternak monogastric dan bersifat prolific (banyak anak tiap kelahiran), pertumbuhannya cepat dan dalam umur enam bulan sudah dapat dipasarkan. Selain itu ternak babi efisien dalam mengkonversi berbagai sisa pertanian menjadi daging. Jika dilihat dari sifat kuantitatif dan kualitatif maka akan terapat perbedaan ternak tersebut. Dari sebanyak 87 bangsa babi terkenal didunia paling sedikit 10 bangsa telah dikembangkan di Indonesia antara lain Landrace, Yorkshire, Duroc, Tamworth, dan Sadle Back. Babi ini umumnya sudah berupa persilangan yang diusahakan pada perusahaan komersial sehingga bangsa murni sulit ditemukan (Aritonang, 1981). Bangsa babi tersebut memiliki sifat-sifat kualitatif yang berbeda dan relatif seragam dalam bangsanya (Lasley, 1978).

Sifat-sifat yang diinginkan peternak adalah sifat yang bermanfaat atau menguntungkan, seperti daya produksi tinggi, jumlah dan bobot anakan saat lahir yang baik, atau pertumbuhan cepat, mortalitas rendah serta efisiensi penggunaan makanan yang tinggi (Fahmy dan Bernard, 1972). Produktivitas ternak ditingkatkan melalui perbaikan genetis dengan seleksi dan perkawinan serta melalui perbaikan lingkungannya (Lasley, 1978).

Salah satu metode perbedaan fenotip dapat dimanfaatkan untuk mengetahui jarak genetik adalah analisis keragaman (Komenes, 1999). Keragaman fenotip dapat diketahui dengan mengukur bagian-bagian tubuh atau morfometrik. Pengukuran ukuran tubuh digunakan untuk membedakan keragaman baik ukuran maupun bentuk tubuh. analisis keragaman dan korelasi banyak digunakan dalam mengkarakterisasi hubungan sifat-sifat fenotip dan genetik (Salako dan Ngere, 2002). Untuk meningkatkan produksi ternak salah satunya yang diperhatikan ialah faktor genetik, ternak yang memiliki hubungan kekerabatan yang dekat dapat diduga akan kecil peluangnya untuk meningkatkan heterosis dalam persilangannya. Maka sebelum melakukan perkawinan perlu diperhatikan jarak genetik antar ternak. Hal ini bertujuan untuk mendapatkan sifat yang lebih unggul atau yang manguntungkan.

Daerah Tapanuli merupakan salah satu sentra produksi babi. Babi yang sering diproduksi ialah Landrace, Duroc, Yorkshire dan Berskhire. Keempat bangsa ini diproduksi dan didapatkan dari BPTU Siborong-borong. Hal ini mempermudah masyarakat dalam mendapatkan bibit untuk beternak dan untuk memenuhi kebutuhan masyarakat akan kebutuhan protein hewani. 
Untuk meningkatkan produksi babi tidak cukup hanya pemberian pakan, manajemen lingkungan melainkan faktor genetik. Hubungan kekerabatan yang dekat atau jarak genetik yang rendah memiliki peluang yang kecil untuk mendapatkan sifat-sifat yang unggul. Maka perlu diketahui jarak genetiknya dari keeampat bangsa tersebut sebelum melakukan persilangan. Jarak genetik bisa menjadi pedoman melakukan persilangan.

\section{BAHAN DAN METODE PENELITIAN}

\section{Lokasi dan Waktu Penelitian}

Penelitian dilaksanakan di Jl. Balige Balai Pembibitan Ternak Unggul (BPTU) Babi dan Kerbau Siborongborong, Kabupaten Tapanuli Utara, Provinsi Sumatera Utara, Bulan September sampai November 2013.

\section{Bahan dan Alat Penelitian}

Keseluruhan ternak yang diamati 110 ekor yang berumur $\geq 1$ tahun yang terdiri dari : 46 ekor babi Landrace (betina 42 ekor dan 4 ekor jantan), 25 ekor babi Yorkshire (betina 22 dan 3 ekor jantan), 22 babi Duroc (18 ekor betina, 4 ekor pejantan), 17 babi Berkshire (11 ekor betina dan 6 ekor jantan). Alat yang digunakan dalam penelitian ini ialah pita ukur $(\mathrm{cm})$ dan tongkat ukur $(\mathrm{cm})$, Alat tulis dan lembar data digunakan untuk mencatat hasil pengamatan dan pengukuran, perangkat lunak SAS (Statistical Analysis System) dan MEGA (Molekuler Evolusioner Genetic Analysis) digunakan untuk menganalisis data.

\section{Metode Analisis}

Metode penelitian yang digunakan adalah metode deskriftif dan analisis diskriminan.

\section{Pengukuran Bagian Tubuh}

Bagian-bagian tubuh babi yang diukur adalah tinggi pundak, tinggi pinggul, lebar pinggul, panjang badan, lingkar dada, dalam dada (Sitorus, 2008), lingkar leher, lebar dada. panjang kepala, lebar kepala, panjang telinga dan lebar telinga (Malewa, 2007). Seluruh ukuran tubuh diukur dalam satuan $\mathrm{cm}$ :

1.Tinggi pundak merupakan jarak tertinggi pundak melalui belakang scapula tegak lurus ke tanah diukur dengan menggunakan tongkat ukur 
2.Tinggi pinggul adalah jarak tertinggi pinggul secara tegak lurus ke tanah, diukur dengan menggunakan tongkat ukur

3.Lebar pinggul, diukur menggunakan tongkat ukur sebagai jarak lebar antara kedua sendi pinggul

4.Panjang badan merupakan jarak garis lurus dari tepi tulang Processus spinocus sampai dengan benjolan tulang lapis (Os ischium), diukur dengan tongkat ukur.

5.Lingkar dada, diukur melingkar tepat dibelakang scapula menggunakan pita ukur

6.Dalam dada merupakan jarak antara titik tertinggi pundak dan tulang dada, diukur dengan menggunakan tongkat ukur

7.Panjang ekor, diukur dengan pita ukur, mulai dari pangkal ekor hingga ujung.

8.Lingkar leher, diukur melingkar pada pertengahan pundak dengan telinga diukur dengan pita ukur.

9.Panjang kepala, diukur pada posisi tengah kepala di antara dua telinga sampai ke bagian mulut menghitam dengan menggunakan pita ukur,

10.Lebar kepala, diukur jarak kedua sisi tulang pipi dengan menggunakan pita ukur.

11.Panjang telinga, diukur dengan pita ukur, dari pangkal telinga hingga ke ujung telinga.

12.Lebar telinga, diukur dari bagian tengah telinga dimulai dari kiri hingga kekanan.

\section{Analisis Data}

\section{Sifat Kuantitatif}

Analisis statistik deskriptif ditunjukkan untuk memperoleh karakterisas ukuran -ukuran tubuh pada babi. Analisis ini dilakılkan dengan menghitung nilai rataan (X), simpangan baku (s) dan koefisien keragaman (KK) dengan prosedur statistik berikut menurut Walpole (1982).

$$
\bar{X}=\frac{\sum_{i-1}^{n} X i}{\mathrm{~N}} \quad S=\sqrt{\frac{\sum_{n-1}^{n}(X i-\bar{X})^{2}}{\cdots}} \quad \mathrm{KK}=\stackrel{s}{=}(100 \%)
$$

\footnotetext{
Keterangan :

$X$ : rata-rata

$\mathrm{S}$ : simpangan baku

$\mathrm{Xi}$ : ukuran ke-i dari peubah $\mathrm{x}$

$\mathrm{n} \quad$ : jumlah sampel yang diambil dari populasi

KK : koefisien keragaman
} 
Untuk membandingkan kelompok antar bangsa babi dilakukan uji-t dengan menggunakan rumus sebagai berikut Walpole (1995) :

\section{Keterangan:}

$$
\mathrm{t}_{\mathrm{h}}=\frac{\bar{x}_{1}-\bar{x}_{2}}{\sqrt{\frac{\sum\left(\mathrm{x}_{1 \mathrm{j}}-\overline{\mathrm{x}}_{1}\right)^{2}}{n_{1\left(\mathrm{n}_{1}-1\right)}}+\frac{\sum\left(\mathrm{x}_{2 \mathrm{j}}-\overline{\mathrm{x}}_{21}\right)^{2}}{n_{2\left(\mathrm{n}_{2}-1\right)}}}}
$$

$\mathrm{t}_{\mathrm{h}} \quad=$ nilai $\mathrm{t}$ hitung

$\mathrm{X}_{1} \quad=$ rataan sampel pada kelompok ke-1

$\mathrm{X}_{2} \quad=$ rataan sampel pada kelompok ke-2

$\mathrm{X}_{\mathrm{ij}} \quad=$ nilai pengamatan ke-j pada kelompok pertama

$\mathrm{X}_{2 \mathrm{j}} \quad=$ nilai pengamatan ke-j pada kelompok kedua

$\mathrm{n}_{1,} \mathrm{n}_{2} \quad=$ jumlah sampel pada kelompok ke- 1 dan ke-2

\section{Analisis Morfometrik}

Jarak genetik ditentukan dengan menggunakan fungsi diskriminan sederhana (D ${ }^{2}$ ). Analisis diskriminan dilakukan menggunakan peubah tinggi pundak, tinggi pinggul, lebar pinggul, panjang badan, lingkar dada, lingkar leher, dalam dada, panjang ekor, panjang kepala, lebar kepala, panjang telinga dan lebar telinga.

Fungsi diskriminan yang digunakan adalah melalui pendekatan jarak Mahalonobis seperti yang dijelaskan oleh Nei (1987) yakni dengan menggabungkan matriks peragam antara peubah dari masing-masing babi yang diamati menjadi sebuah matriks. Statistik $\mathrm{D}^{2}$-Mahalanobis dihitung dengan rumus berdasarkan Gazpersz (1992).

Keterangan:

$$
\mathrm{D}_{(\mathrm{i}, \mathrm{j})}^{2}=\left(X_{i}-X_{j}\right) C^{l}\left(X_{i}-X_{j}\right)
$$

\footnotetext{
$D_{(i, j)}^{2}:$ Nilai statistik Mahalanobis sebagai ukuran jarak kuadrat genetik antar kelompok babi ke-i dan kelompok babi ke-j;

$C^{-1} \quad:$ Kebalikan matrik gabungan ragam peragam antar peubah;

$X_{I} \quad$ : Vektor nilai rataan pengamatan dari kelompok babi ke-i pada masing-masing peubah kuantitatif; dan

$X_{j} \quad$ : Vektor nilai rataan pengamatan dari kelompok babi ke-j pada masing-masing peubah kuantitatif.
}

Setelah perhitungan jarak kuadrat, kemudian dilakukan pengakaran terhadap hasil kuadrat jarak, agar jarak genetik yang didapat bukan dalam bentuk kuadrat. Hasil pengakaran dianalisis lebih lanjut dengan program MEGA untuk memperoleh pohon fenogram (Kumar et al., 1993). Dengan asumsi bahwa laju evolusi antar kelompok babi adalah sama. 
Analisis statistik Mahalanobis dikerjakan menggunakan paket program SAS dengan prosedur PROC CANDISC dan PROC DISCRIM. Penentuan penyebaran babi dan nilai kesamaan diantara bangsa babi digunakan analisis kanonikal. Analisis ini juga digunakan dalam menentukan beberapa peubah ukuran fenotipik yang memiliki pengaruh kuat terhadap penyebab terjadinya pengelompokkan antara bangsa babi. Prosedur analisisnya menggunakan PROC CANDISC dari SAS (SAS, 1989).

\section{HASIL DAN PEMBAHASAN}

\section{Perbandingan Morfometrik Bangsa Babi}

Rataan dan simpangan baku ukuran tubuh ternak bangsa babi disajikan pada Tabel 1. Jumlah semua babi yang diamati adalah 110 ekor, diantaranya babi Landrace 46 ekor, Yorkshire 25 ekor, Duroc 22 ekor dan Berkshire 17 ekor. Hasil penelitian menunjukkan bahwa bangsa babi Berkshire memiliki ukuran tubuh yang lebih kecil dibandingkan dengan babi Yorkshire, Duroc dan Landrace kecuali pada panjang badan $(91,07 \pm 10,397 \mathrm{~cm})$, tinggi pundak $(80,95 \pm 9,483 \mathrm{~cm})$ dan lebar pinggul $(26,62 \pm 2,560 \mathrm{~cm})$. Kecilnya ukuran tubuh bangsa babi Berkshire diduga persilangan yang kurang ketat dalam meningkatkan sifat-sifat yang lebih unggul serta manajemen perkandangan dan pakan.

Bangsa babi Duroc memiliki ukuran tubuh yang terbesar yaitu pada peubah tinggi pundak $(84,53 \pm 4,324 \mathrm{~cm})$, tinggi pinggul $(89,09 \pm 4,055 \mathrm{~cm})$, lebar kepala $(30,63 \pm 2,058 \mathrm{~cm})$ panjang kepala $(36,20 \pm 2,201)$, lingkar leher $(98,93 \pm 5,942 \mathrm{~cm})$, dalam dada $(48,13 \pm 3,874 \mathrm{~cm})$ dan lebar pinggul $(27,04 \pm 2,247 \mathrm{~cm})$.

Soeparno (1992) menyatakan perbedaan komposisi tubuh diantara bangsa ternak terutama disebabkan oleh perbedaan ukuran tubuh dewasa. Faktor lingkungan dan genetik mempunyai hubungan yang erat untuk mengekspresikan kapasitas genetik individu secara sempurna diperlukan kondisi lingkungan yang ideal.

Koefisien keragaman pada bangsa babi disajikan pada Tabel 1. Hasil penelitian menunjukkan keragaman yang lebih tinggi dari masing-masing peubah atau lebih dominan tidak seragam terdapat pada bangsa babi Berkshire yaitu panjang badan (11,41\%), tinggi pundak $(11,71 \%)$, tinggi pinggul $(7,81 \%)$, lebar telinga $(12,02 \%)$, panjang telinga $(13,81)$ lingkar leher $(10,15 \%)$ dan lebar pinggul $(9,61 \%)$. 
Tabel 1. Rataan, simpangan baku, koefisien keragaman ukuran-ukuran tubuh bangsa babi (umur $\geq 1$ tahun).

\begin{tabular}{|c|c|c|c|}
\hline Ukuran Tubuh & Bangsa Babi & $\bar{x} \pm s(\mathbf{c m})$ & KK $(\%)$ \\
\hline \multirow{4}{*}{ Panjang Badan } & Landrace & $91,33^{\mathrm{A}} \pm 8,476$ & 9,28 \\
\hline & Yorkshire & $91,47^{\mathrm{A}} \pm 8,816$ & 9,63 \\
\hline & Duroc & $89,61^{\mathrm{A}} \pm 4,324$ & 4,82 \\
\hline & Berkshire & $91,07^{\mathrm{A}} \pm 10,397$ & 11,41 \\
\hline \multirow[t]{4}{*}{ Tinggi Pundak } & Landrace & $80,46^{\mathrm{B}} \pm 7,008$ & 8,70 \\
\hline & Yorkshire & $79,43^{\mathrm{B}} \pm 6,235$ & 7,84 \\
\hline & Duroc & $84,53^{\mathrm{A}} \pm 4,324$ & 5,11 \\
\hline & Berkshire & $80,95^{\mathrm{AB}} \pm 9,483$ & 11,71 \\
\hline \multirow[t]{4}{*}{ Tinggi Pinggul } & Landrace & $86,09^{\mathrm{AB}} \pm 5,296$ & 6,15 \\
\hline & Yorkshire & $86,30^{\mathrm{AB}} \pm 5,064$ & 5,86 \\
\hline & Duroc & $89,09^{\mathrm{A}} \pm 4,055$ & 4,55 \\
\hline & Berkshire & $85,51^{\mathrm{B}} \pm 6,679$ & 7,81 \\
\hline \multirow[t]{4}{*}{ Lebar Telinga } & Landrace & $19,34^{\mathrm{A}} \pm 1,371$ & 7,08 \\
\hline & Yorkshire & $16,75^{\mathrm{B}} \pm 1,673$ & 9,98 \\
\hline & Duroc & $16,72^{\mathrm{B}} \pm 1,323$ & 7,91 \\
\hline & Berkshire & $16,12^{\mathrm{B}} \pm 1,938$ & 12,02 \\
\hline \multirow[t]{4}{*}{ Panjang Telinga } & Landrace & $21,35^{\mathrm{A}} \pm 1,828$ & 8,56 \\
\hline & Yorkshire & $17,38^{\mathrm{B}} \pm 1,827$ & 10,51 \\
\hline & Duroc & $17,68^{\mathrm{B}} \pm 1,228$ & 6,94 \\
\hline & Berkshire & $17,27^{\mathrm{B}} \pm 2,385$ & 13,81 \\
\hline \multirow[t]{4}{*}{ Lebar Kepala } & Landrace & $28,76^{\mathrm{B}} \pm 2,906$ & 10,10 \\
\hline & Yorkshire & $28,20^{\mathrm{B}} \pm 2,568$ & 9,10 \\
\hline & Duroc & $30,63^{\mathrm{A}} \pm 2,058$ & 6,71 \\
\hline & Berkshire & $27,35^{\mathrm{B}} \pm 2,716$ & 9,93 \\
\hline \multirow[t]{4}{*}{ Panjang Kepala } & Landrace & $32,36^{\mathrm{B}} \pm 2,739$ & 8,46 \\
\hline & Yorkshire & $32,84^{\mathrm{B}} \pm 2,167$ & 6,59 \\
\hline & Duroc & $36,20^{\mathrm{A}} \pm 2,201$ & 6,08 \\
\hline & Berkshire & $30,35^{\mathrm{C}} \pm 2,366$ & 7,79 \\
\hline \multirow[t]{4}{*}{ Panjang Ekor } & Landrace & $34,24^{\mathrm{A}} \pm 5,167$ & 15,09 \\
\hline & Yorkshire & $34,68^{\mathrm{A}} \pm 3,877$ & 11,17 \\
\hline & Duroc & $33,26^{\mathrm{A}} \pm 3,390$ & 10,19 \\
\hline & Berkshire & $28,93^{\mathrm{B}} \pm 2,352$ & 8,12 \\
\hline \multirow[t]{4}{*}{ Lingkar Dada } & Landrace & $139,04^{\mathrm{A}} \pm 10,347$ & 7,44 \\
\hline & Yorkshire & $135,86^{\mathrm{A}} \pm 9,255$ & 6,81 \\
\hline & Duroc & $137,20^{\mathrm{A}} \pm 28,621$ & 20,8 \\
\hline & Berkshire & $131,50^{\mathrm{A}} \pm 14,529$ & 11,04 \\
\hline \multirow[t]{4}{*}{ Lingkar Leher } & Landrace & $98,87^{\mathrm{A}} \pm 7,310$ & 7,39 \\
\hline & Yorkshire & $98,46^{\mathrm{A}} \pm 5,586$ & 5,67 \\
\hline & Duroc & $98,93^{\mathrm{A}} \pm 5,942$ & 6,00 \\
\hline & Berkshire & $95,75^{\mathrm{A}} \pm 9,719$ & 10,15 \\
\hline \multirow[t]{4}{*}{ Dalam Dada } & Landrace & $47,84^{\mathrm{A}} \pm 7,639$ & 15,96 \\
\hline & Yorkshire & $45,90^{\mathrm{A}} \pm 3,849$ & 8,38 \\
\hline & Duroc & $48,13^{\mathrm{A}} \pm 3,874$ & 8,04 \\
\hline & Berkshire & $45,72^{\mathrm{A}} \pm 5,908$ & 12,92 \\
\hline \multirow[t]{4}{*}{ Lebar Pinggul } & Landrace & $26,87^{\mathrm{A}} \pm 1,597$ & 5,94 \\
\hline & Yorkshire & $26,58^{\mathrm{A}} \pm 1,662$ & 6,25 \\
\hline & Duroc & $27,04^{\mathrm{A}} \pm 2,247$ & 8,30 \\
\hline & Berkshire & $26,62^{\mathrm{A}} \pm 2,560$ & 9,61 \\
\hline
\end{tabular}

Ket : Huruf superskrip yang berbeda pada peubah yang sama menunjukkan berbeda nyata $(\mathrm{P}<0,05)$. 
Tingginya keragaman ini diduga karena tidak adanya seleksi dan terdapat perbedaan manajemen kandang dan pakan. Keragaman yang lebih rendah dari keempat bangsa terdapat pada bangsa babi bangsa Duroc yaitu panjang badan $(4,82 \%)$, tinggi pundak $(5,11 \%)$, tinggi pinggul $(4,55 \%)$, panjang telinga $(6,94 \%)$, lebar kepala $(6,71 \%)$, panjang kepala $(6,08 \%)$ dan dalam dada $(8,04 \%)$.

Keragaman bangsa babi Duroc rendah diduga menggunakan pejantan yang sama dalam persilangan. Ukuran tubuh bangsa babi Yorkshire dengan Duroc secara umum lebih seragam pada dalam dada $(8,38 \%$ dengan $8,04 \%)$ dan Landrace dengan Yorkshire pada ukuran panjang badan (9,28\% dengan 9,63\%). Keseragaman Landrace dengan Yorkshire pada ukuran panjang badan hal ini diduga kekerabatan yang dekat, seperti hasil penelitian Kim et al, (2005) yang menunjukkan bahwa babi bangsa Landrace dengan Yorkshire memiliki jarak genetik yang kecil.

\section{Peubah Pembeda Bangsa Babi}

Tabel 2 menunjukkan total struktur kanonik bangsa babi, yang merupakan analisis diskriminan. Gunawan dan Sumantri (2008) menyatakan analisis diskriminan juga dipakai untuk menentukan beberapa peubah dari ukuran fenotipik yang memiliki pengaruh kuat terhadap penyebab terjadinya pengelompokan ternak (pembeda kelompok).

Wiley (1981), menyatakan bahwa analisis variat kanonikal digunakan untuk mendapatkan kombinasi karakter yang membedakan secara keseluruhan dan dapat digunakan untuk menggambar plot skor guna membandingkan didalam dan diantara variabilitas populasi (kelompok babi) pada dimensi yang kecil.

Tabel 2. Total struktur kanonikal bangsa babi (Berkshire, Duroc, Landrace dan Yorkshire).

\begin{tabular}{lccl}
\hline Variable Ukuran Tubuh & KAN1 & KAN2 & KAN3 \\
\hline Panjang Badan & 0.060448 & -0.084212 & 0.064974 \\
Tinggi Pundak & -0.149611 & 0.258893 & 0.243913 \\
Tinggi Pinggul & -0.150084 & 0.281440 & 0.033972 \\
Lebar Telinga & $\mathbf{0 . 7 8 9 3 6 0}$ & 0.248517 & 0.017922 \\
Panjang Telinga & $\mathbf{0 . 8 5 7 7 0 3}$ & 0.234587 & 0.136794 \\
Lebar Kepala & -0.083594 & $\mathbf{0 . 5 1 6 6 9 9}$ & 0.055097 \\
Panjang Kepala & -0.291984 & $\mathbf{0 . 7 7 6 8 7 4}$ & 0.150142 \\
Panjang Ekor & 0.202780 & 0.316366 & $\mathbf{0 . 5 9 6 1 6 2}$ \\
Lingkar Dada & 0.130125 & 0.159838 & 0.080786 \\
Lingkar Leher & 0.068042 & 0.176399 & 0.142334 \\
Dalam Dada & 0.088901 & 0.210969 & 0.086462 \\
Lebar Pinggul & 0.019493 & 0.114374 & 0.068058 \\
\hline
\end{tabular}

Keterangan : KAN = Kanonikal 
Berdasarkan hasil analisis dapat diketahui peubah-peubah ukuran tubuh yang memberi pengaruh kuat yang membedakan antar bangsa babi adalah lebar telinga $(0,789369)$, panjang telinga $(0,857703)$ pada KAN-1, lebar kepala $(0,516699)$, panjang kepala $(0,776874)$ pada KAN2 dan panjang ekor $(0,596162)$ pada KAN-3. Pendugaan tersebut didasarkan pada tingginya nilai kanonikal dari peubah lebar telinga, panjang telinga, lebar kepala, panjang kepala dan panjang ekor.

\section{Nilai Campuran Fenotifik antar Bangsa Babi}

Analisis diskriminan juga dapat digunakan sebagai kriteria pengelompokan berdasarkan perhitungan statistik terhadap kelompok yang telah diketahui dengan jelas pengelompokannya hal ini pernyataan Gazpers (1992). Dengan demikian analisis diskriminan dapat digunakan untuk mengetahui nilai kesamaan fenotifik antar bangsa babi dan sebangsanya, persentasenya disajikan pada Tabel 3.

Tabel 3. Persentase kesamaan fenotifik dalam bangsa dan antar bangsa babi (Berkshire, Duroc, Landrace dan Yorkshire).

\begin{tabular}{lcccl}
\hline Bangsa Babi & Berkshire & Duroc & Landrace & Yorkshire \\
\hline Berkshire & 88,24 & 0,00 & 5,88 & 5,88 \\
Duroc & 0,00 & 86,36 & 0,00 & 13,64 \\
Landrace & 2,17 & 2,17 & 89,13 & 6,52 \\
Yorkshire & 8,00 & 20,00 & 4,00 & 68,00 \\
\hline
\end{tabular}

Nilai kesamaan dalam bangsa dan antar bangsa babi dapat menunjukkan pendugaan tingkat kemurnian fenotifik dari bangsa babi tersebut. Menurut Soeparno (1992) Faktor lingkungan dan genetik mempunyai hubungan yang erat untuk mengekspresikan kapasitas genetik individu secara sempurna diperlukan kondisi lingkungan yang ideal. Maka faktor lingkungan sangat berpengaruh untuk nilai kesamaan fenotifik.

Hasil analisis menunjukkan nilai kesamaan fenotifik paling rendah dalam bangsa ialah bangsa babi Yorkshire yaitu sebesar 68,00\%. Fenotifik bangsa babi Yorkshire dipengaruhi oleh tiga bangsa babi lainnya, yang lebih dominan mempengaruhi ialah bangsa babi Duroc yaitu sebesar 20,00\%. Hal ini menunjukkan kemurnian bangsa babi Yorkshire sangat rendah dan banyak tercampur oleh darah bangsa Duroc. Diantara empat bangsa babi terdapat bangsa babi Yorkshire dan Duroc yang memiliki kesamaan fenotifik tertinggi yaitu sebesar 20,00\%. Tingginya kesamaan babi Yorkshire dengan Duroc dapat dipengaruhi oleh sistem tatalaksana perkandangan dan faktor genetik seperti pernyataan Noor (1995) kesamaan atau keragaman 
fenotifik disebabkan interaksi genetik dengan lingkungan. Kesamaan fenotifik tertinggi terdapat pada bangsa babi Landrace yaitu sebesar 89,13\%, mendapat pengaruh dari bangsa Berkshire 2,17 \%, dari bangsa babi Duroc 2,17 \% dan bangsa Yorkshire 6,52 \%. Hal ini menunjukkan bangsa babi Landrace lebih murni dan sedikit tercampur dengan darah ketiga bangsa babi lainnya.

\section{Peta Penyebaran Bangsa Babi}

Gambar 1 menyajikan peta penyebaran bangsa babi berdasarkan ukuran-ukuran tubuh yang menggambarkan pemisahan antar bangsa babi.

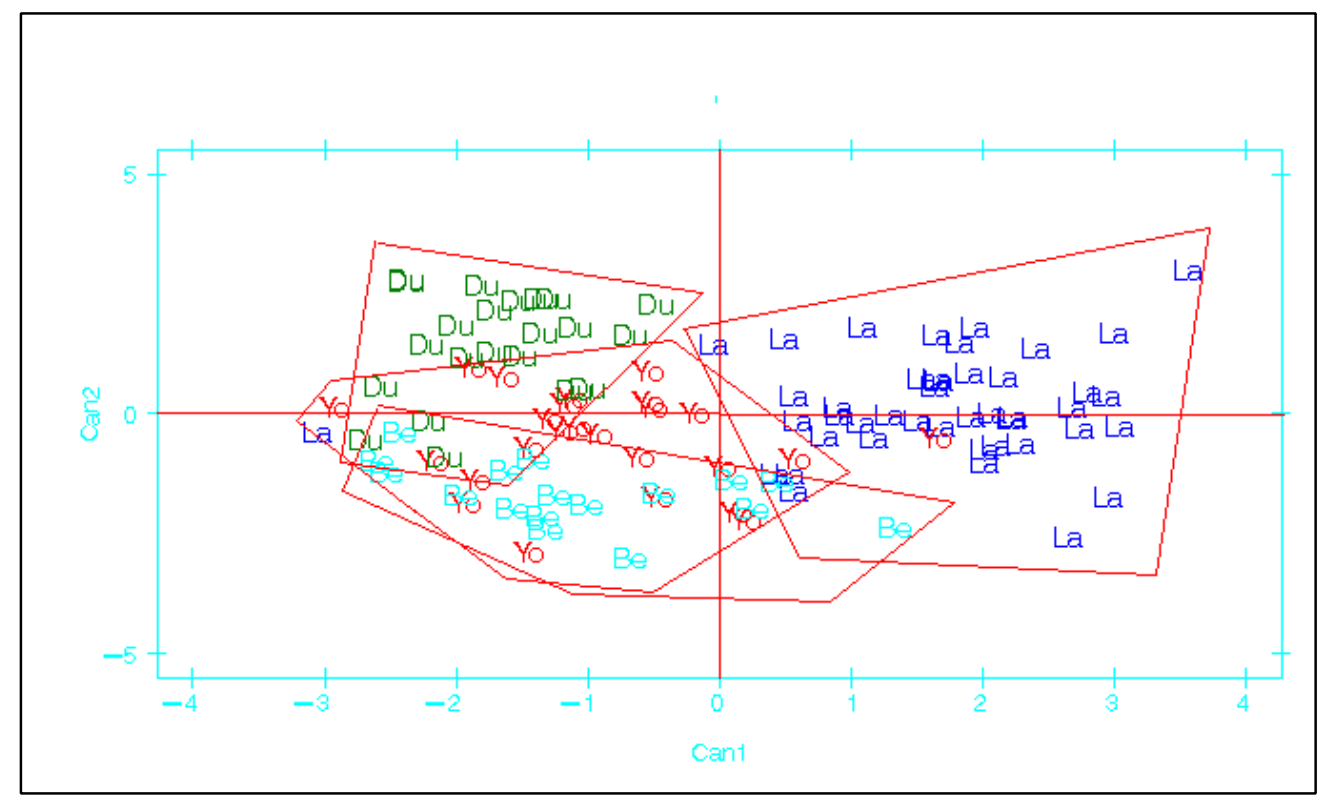

Gambar 1. Plot Kanonikal Penyebaran Bangsa Babi 
Afifi dan Clark (1996) menyatakan bahwa plot data hasil analisis diskriminan dapat digunakan untuk menggambarkan pemisahan maksimum yang mungkin terjadi antar kelompok yang diuji. Hasil analisis pada Gambar 1 memperlihatkan bahwa bangsa babi Landrace dominan mengelompok ke sebelah kanan atas aksis $\mathrm{Y}$ yang memperlihatkan penampilan fenotifik yang berbeda dibandingkan dengan bangsa babi lainnya walaupun terdapat menyebar ke sebelah kanan bawah aksis Y. Kemudian bangsa babi Duroc mengelompok lebih dominan ke sebelah kiri atas aksis $\mathrm{Y}$ walaupun terdapat kerumun bangsa babi Yorkshire. Begitu juga bangsa babi Berkshire mengelompok ke sebelah kiri bawah aksis Y terdapat kerumun babi bangsa Yorkshire.

Peta penyebaran kelompok bangsa babi menggambarkan bahwa bangsa babi Landrace memiliki ukuran tubuh yang berbeda atau jarak yang jauh dengan bangsa babi Duroc, begitu juga dengan bangsa babi Duroc dengan bangsa babi Berkshire, sedangkan bangsa babi Duroc dengan bangsa babi Yorkshire kerumunannya berdekatan sehingga diduga terdapat beberapa kesamaan fenotifiknya. Pengamatan ini didukung dari hasil nilai campuran fenotifik antar bangsa babi.

\section{Penentuan Estimasi Jarak Genetik dan Dendogram antar Bangsa Babi}

Nilai matrik jarak antar masing-masing bangsa babi dapat dilihat pada Tabel 4, nilai tersebut didapat dari hasil analisis diskriminan yang menghasilkan kuadrat jarak antar bangsa babi yang diamati

Penentuan jarak genetik berdasarkan karakteristik ukuran tubuh menunjukkan jarak terdekat ditemukam antara bangsa babi Berkshire dengan bangsa babi Yorkshire yaitu sebesar 4,89982. Jarak genetik terjauh ditemukan antara bangsa babi Duroc dengan bangsa babi Landrace sebesar 13,04031. Hal ini tidak sepenuhnya sama dengan hasil penelitian Kim et al, (2005) yang menyatakan jarak genetik yang terdekat didapat pada bangsa babi Landrace dengan Yorkshire, yang terjauh didapat pada bangsa babi Duroc dengan Landrace. Tidak samanya sepenuhnya hasil penelitan diduga karena metode penelitian yang digunakan berbeda. Kim et al, (2005) menggunakan metode analisis tingkat DNA menggunakan 16 penanda mikrosatelit dengan sampel 126 ekor (Berkshire $=30$ ekor, Duroc $=32$ ekor, Landrace $=32$ ekor dan Yorkshire $=32$ ekor . 
Tabel 4. Matriks jarak genetik bangsa babi

\begin{tabular}{lllll}
\hline Bangsa Babi & Berkshire & Duroc & Landrace & Yorkshire \\
\hline Berkshire & 0 & - & - & - \\
Duroc & 10,43824 & 0 & - & - \\
Landrace & 11,42517 & 13,04031 & 0 & - \\
Yorkshire & 4,89982 & 6,60116 & 8,25065 & 0 \\
\hline
\end{tabular}

Dendogram yang disajikan pada Gambar 2 diperoleh dari matriks jarak genetik dari Tabel 4. Dendogram dibuat dengan metode UPGMA (Nei, 1987). Dendogram menunjukkan bangsa babi Berkshire dengan bangsa babi Yorkshire memiliki kekerabatan yang dekat (4,89982). Berdasarkan nilai ini persilangan antara babi bangsa Berkshire dan bangsa babi Yorkshire tidak akan memberikan kemajuan kuantitatif yang signifikan, apabila tidak disertai dengan sistem seleksi yang ketat, hal ini disebabkan karena kecilnya peluang terjadinya heterosis pada hasil persilangannya. Bangsa babi yang memiliki kekerabatan yang jauh ialah bangsa babi Landrace dan bangsa babi Duroc $(13,04031)$ dan hasil ini sesuai dengan penelitian Kim et al, (2005). Hal ini menunjukkan memiliki peluang yang besar untuk meningkatkan terjadinya heterosis pada hasil persilangan.

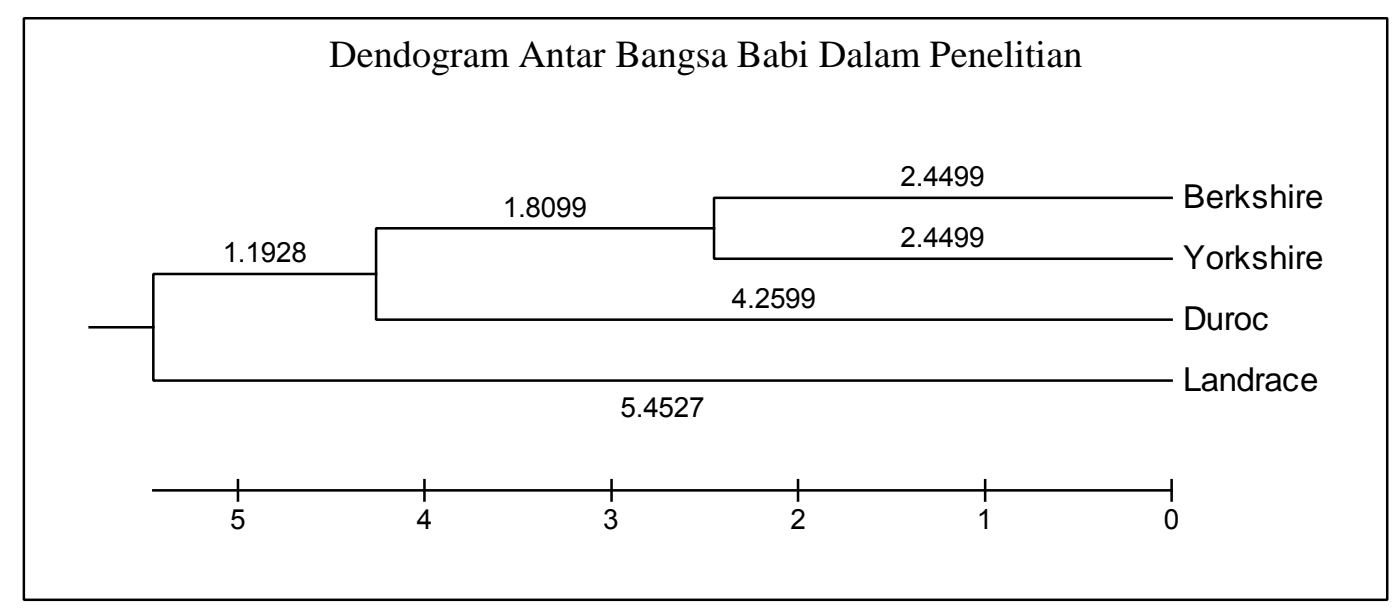

Gambar 2. Dendogram bangsa babi Berkshire, Yorkshire, Duroc dan Landrace 


\section{KESIMPULAN}

Keragaman ukuran-ukuran tubuh yang tertinggi terdapat pada bangsa babi Berkshire dan yang terendah atau lebih seragam terdapat pada bangsa babi Duroc. Hasil analisis diskriminan dari nilai campuran fenotifik menunjukkan bangsa babi Yorkshire dan bangsa babi Duroc memiliki ukuran tubuh yang lebih dekat dibandingkan bangsa babi Landrace dan Berkshire. Peubah yang membedakan keempat bangsa babi adalah lebar telinga, panjang telinga, lebar kepala, panjang kepala dan panjang ekor. Persentase kemurnian fenotifik masing-masing bangsa babi dari terbesar sampai terkecil ialah Landrace 89,13\%, Berkshire 88,24\%, Duroc 86,36\% dan Yorkshire 68,00\%. Bangsa babi Berkshire dengan bangsa babi Yorkshire memiliki hubungan kekerabatan yang dekat, sebaliknya bangsa babi Duroc dengan bangsa babi Landrace memiliki hubungan kekerabatan yang jauh.

\section{DAFTAR PUSTAKA}

Afifi, A.A. dan V. Clark. 1996. Computer-Aided Multivariate Analysis. $3^{\text {rd }}$ Edition. Chapman and Hall/CRC, New York.

Aritonang, D. 1981. Peranan peternakan babi dalam pembangunan peternakan di Indonesia. Ranch. 8,9:40-42.

Fahmy, M.M. dan C.S. Bernard. 1972. Interrelations between some reproductive traits in swine. Can. J. Anim. Sci. 52:39.

Gazpers, V. 1992. Teknik Analisis dalam Perancangan Percobaan Penelitian. Tarsito, Bandung.

Gunawan A, dan Sumantri C. 2008. Pendugaan nilai campuran fenotipik dan jarak genetik domba Garut dan persilangannya. J Indon Trop Anim Agric 33(3): 176-185.

Kim, T.H.,K.S.Kim., B.H. Choi., D.H. Yoon., G.W. Jang., K.T. Lee., H.Y. Chung., H.Y.Lee., H.S Park dan J.W.Lee. 2005. Genetic Structure of Pig Breeds from Korea and China Using Microsatellite loci Analysis. Iowa State University. http://www.journalofanimalscience.org [diakses pada 22 November 2013].

Komenes, P.A. 1999. Alfa-casein and beta-lactoglobulin and growth hormone alleles frequencies and genetik distances in Nelore, GYR, Guzera, Caracu, Charolais, Canchim and Santa Getrudis cattles. Gen Mol Biol 22:539-541.

Kumar, S., K. Tamura and M. Nei 1993. MEGA. Molecular Evolutionary Genetics Analysis. Version 1.01. Institute of Molecular Evolutioner Genetic. The Pennsylvania University. USA.

Lasley, T.J. 1978. Genetic of Livestock Improvement. 3rd Ed. Prentice Hall of India Private Ltd. New Delhi.

Malewa, A. Dg. 2007. Karakteristik Fenotipe dan Jarak Genetik Domba Donggala di Tiga Lokasi di Sulawesi Tengah. Tesis. Sekolah Pasca Sarjana. Institut Pertanian Bogor.

Nei, M. 1987. Moleculer Evolutionary Genetic. Columbia University Press. USA.

Noor. 2008. Genetika Ternak. Ed ke-4. Depok: PT. Penebar Swadaya. Jakarta. 
Salako, A.E., dan L. O Ngere. 2002. Application of multifactorial discriminant analysis in the morphometric structural differentiation of the WAD and Yankasa sheep in the humid southwest Nigeria. Nig. J. Anim. Prod. 29(2):163-7.

SAS Institute. 1989. SAS/STAT Guide for Personal Computer. Version 6 Edit. SAS Institut Cary, NC. USA.

Sitorus, A. J. 2008. Studi Keragaman Fenotipe dan Pendugaan Jarak Genetik Kerbau Sungai, Rawa dan Silangannya di Sumatera Utara. Skripsi. Fakultas Peternakan. Institut Pertanian Bogor.

Soeparno. 1992. Ilmu dan Teknologi Daging. Gadjah Mada University Press. Yogyakarta.

Walpole, R. 1982. Pengantar Statistika. Terjemahan : B. Sumantri. Gramedia, Jakarta.

Wiley, E. O. 1981. Phylogenetics: The Theory and Practice of Phylogenetic Systematics. Jhon Wiley \& Sons Inc., Canada. 